\title{
CHARACTERIZING SUBMARINE GROUND-WATER DISCHARGE USING FIBER-OPTIC DISTRIBUTED TEMPERATURE SENSING AND MARINE ELECTRICAL RESISTIVITY
}

\author{
Rory D. Henderson, U.S. Geological Survey, Storrs, CT and University of Connecticut, Storrs, CT \\ Frederick D. Day-Lewis, U.S. Geological Survey, Storrs, CT \\ John W. Lane, Jr., U.S. Geological Survey, Storrs, CT \\ Charles F. Harvey, Massachusetts Institute of Technology, Cambridge, MA \\ Lanbo Liu, University of Connecticut, Storrs, CT
}

\begin{abstract}
Submarine ground-water discharge (SGD) contributes important solute fluxes to coastal waters. Pollutants are transported to coastal ecosystems by SGD at spatially and temporally variable rates. New approaches are needed to characterize the effects of storm-event, tidal, and seasonal forcing on SGD. Here, we evaluate the utility of two geophysical methods-fiber-optic distributed temperature sensing (FO-DTS) and marine electrical resistivity (MER)-for observing the spatial and temporal variations in SGD and the configuration of the freshwater/saltwater interface within submarine sediments. FO-DTS and MER cables were permanently installed into the estuary floor on a transect extending 50 meters offshore under Waquoit Bay, Massachusetts, at the Waquoit Bay National Estuarine Research Reserve, and nearly continuous data were collected for 4 weeks in summer 2007.

Initial results indicate that the methods are extremely useful for monitoring changes in the complex estuarine environment. The FO-DTS produced time-series data at approximately 1-meter increments along the length of the fiber at approximately 29-second intervals. The temperature timeseries data show that the temperature at near-shore locations appears to be dominated by a semi-diurnal (tidal) signal, whereas the temperature at off-shore locations is dominated by a diurnal signal (day/night heating and cooling). Dipole-dipole MER surveys were completed about every 50 minutes, allowing for production of high-resolution time-lapse tomograms, which provide insight into the variations of the subsurface freshwater/saltwater interface. Preliminary results from the MER data show a high-resistivity zone near the shore at low tide, indicative of SGD, and consistent with the FO-DTS results.
\end{abstract}

\section{Introduction}

Submarine ground-water discharge (SGD) is an important source of nutrients and contaminants to coastal ecosystems (Johannes, 1980; Simmons, 1992; Moore, 1999; Burnett et al., 2003; Colman et al., 2004; Miller and Ullman, 2004; Slomp and Van Cappellen, 2004). While the rates and chemistry of SGD are known to vary in space and time, additional research is needed to clarify the roles of episodic (storm-related) and periodic (tidal, seasonal) forcing on SGD. Conventional approaches to SGD characterization rely on (1) direct measurements of seepage and sub-bottom salinity (e.g., Michael et al., 2003); (2) indirect measurement of vertical temperature profiles, from which discharge rates are inferred by calibrating convection-conduction models (e.g., Taniguchi et al., 2003); (3) measurements of geochemical tracers for use in mass balance calculations incorporating advective transport through sediments (Burnett et al., 2006); and (4) water balance methods which depend on numerical models to

Final copy as submitted to SAGEEP for publication as: Henderson, R.D., Day-Lewis, F.D., Lane, J.W., Jr., Harvey, C.F., and Liu, L., 2008, Characterizing submarine ground-water discharge using fiber-optic distributed temperature sensing and marine electrical resistivity, in Symposium on the Application of Geophysics to Engineering and Environmental Problems, April 6-10, 2008, Philadelphia, Pennsylvania, Proceedings: Denver, Colorado, Environmental and Engineering Geophysical Society, 11p. 
quantify average SGD rates over large spatial areas (Smith and Nield, 2003).

The geometry of the freshwater/saltwater interface commonly is assumed to follow the GhybenHerzberg approximation (Bear, 1979) on the density difference between freshwater and saltwater and the assumption of hydrostatic conditions, the Ghyben-Herzberg approximation predicts that a coastal, unconfined aquifer extends below sea level 40 times the water table elevation above sea level. Under equilibrium conditions, the interface would be stationary, intersecting the shoreline such that no SGD would occur. However, under non-equilibrium conditions, SGD rates and spatial distributions are complex and vary seasonally.

The Waquoit Bay National Estuarine Research Reserve (WBNERR) is located in East Falmouth, on Cape Cod, Massachusetts (Figure 1). The bay is approximately 3 square kilometers, has an average depth of about 1 meter (m), and receives about 46 centimeters of precipitation annually (Cambareri and Eichner, 1998). The Cape Cod aquifer is unconfined and 100 to 120-m thick. In the Waquoit Bay area, an approximately 11-m-thick permeable layer overlies a less permeable layer of fine sand, silt, and clay. Glacial till and bedrock bound the upper sediments (Michael et al., 2003).

SGD has been the focus of several studies at WBNERR (e.g., Heofel and Evans, 2001; Abraham et al., 2003; Belaval et al., 2003; Michael et al., 2005; Mulligan and Charette, 2005). Variations in SGD occur at several time scales at Waquoit Bay. On a seasonal scale, the freshwater/saltwater interface shifts landward in early winter due to a lack of recharging precipitation in the late summer and fall, and saline waters are drawn from the bay into the aquifer. In response to land-based recharge during the spring to early summer, the interface moves seaward in late summer, effectively displacing the saline waters recharged through the bay sediments to create conditions of saline outflow (Michael et al., 2005). Semi-monthly variations were observed in response to changing tidal range. SGD appeared to increase from neap to spring tide (where the tidal range is increasing) and decrease from spring to neap tide (where the tidal range is decreasing), consistent with the findings of Taniguchi (2002) in Osaka Bay, Japan. Additionally, semi-diurnal variations caused by the daily tidal cycle influence near-shore discharge patterns. As the tide increases, saltwater infiltrates the beach face in the intertidal zone and begins to counter discharge. The process is reversed as the tide falls and discharge continues with both freshwater and saltwater components (Urish and McKenna, 2004).

Conventional approaches to characterizing SGD are time-consuming and labor-intensive (i.e., seepage measurements and geochemical tracer measurements); provide information at only sparse locations (i.e., vertical temperature profiles); or offer only large scale estimates (i.e., water balance methods). New approaches are needed to better characterize the spatial and temporal variations of SGD to understand the roles of episodic, tidal, and seasonal forcing. In this study, we use fiber-optic distributed temperature sensing (FO-DTS) techniques (e.g., Selker et al., 2006) and time-lapse marine electrical resistivity (MER) (e.g., Belaval et al., 2003; Manheim, et al., 2004; Day-Lewis et al., 2006; Swarzenski et al., 2006) to monitor SGD and the freshwater/saltwater interface and to provide highresolution data at near-continuous time and spatial scales.

\section{Methods}

Use of temperature measurements to monitor SGD relies on the contrast between the temperatures of fresh ground water and brackish-to-saline surface water. Whereas ground-water temperature is relatively stable year round, surface-water temperature changes daily, seasonally, and with weather systems; hence, SGD generally manifests as cold anomalies in summer and warm anomalies in winter. FO-DTS is a new technology that can provide temperature measurements the full length of the fiber-optic cable, which can extend up to tens of kilometers. With current technology, spatial resolution of $1 \mathrm{~m}$, temporal resolution on the order of 1 minute, and temperature precision of about $0.1{ }^{\circ} \mathrm{C}$ are feasible (Lane et al., in press). Most commercially available systems used for 
hydrologic studies use the phenomenon of Raman scattering to measure temperature. Raman scattering occurs as light interacts with the fiber materials, producing backscatter energy that is temperaturedependent (anti-Stokes scattering) and temperature-independent (Stokes scattering). The ratio of the magnitudes of the anti-Stokes to Stokes scattering depends exponentially on the fiber temperature (Selker et al., 2006).

At Waquoit Bay, a standard 62.5-micron telecommunication fiber-optic cable was used for the field experiment. The FO-DTS cable was permanently installed into the estuary floor on a transect extending $50 \mathrm{~m}$ off shore. Temperature data were collected continuously from 4 June to 16 July 2007 using a Lios 2000/4000 OTS $^{1}$. The instrument fires a pulse of light and measures the incident backscatter energy. The spatial resolution of the instrument was $1.05 \mathrm{~m}$, and data were collected at approximately 29-second intervals.

The use of MER to delineate the freshwater/saltwater interface is dependent on the conductivity contrast between less conductive freshwater and more conductive saltwater. We used a Multi-Phase Technologies, LLC, MPT-ERT resistivity and IP monitoring system to collect the MER data. The system requires use of a separate power supply to generate the injected current. The resistivity cable has 48 graphite electrodes at 1-m spacing and was co-located with the fiber-optic cable. The electrodes were installed into the estuary floor, to a depth of approximately $0.5 \mathrm{~m}$, to maximize repeatability of measurements for time-lapse imaging and comparison of results from periodic surveys, minimize cable movement resulting from storms, and ensure good electrical contact with estuarine sediments. MER surveys have been conducted with vessel-towed arrays (Belaval et al., 2003; Day-Lewis et al., 2006), but time-lapse imaging assumes that electrodes reoccupy the same locations and repeatability can be problematic for towed arrays. The resistivity surveys were conducted using a dipole-dipole survey geometry. One measurement cycle (including reciprocal data) took approximately 50 minutes to complete, and surveys were conducted nearly continuously from 4 June to 2 July 2007. Inversions were performed using RES2DINV (Loke, 2004), accounting for estuary-floor topography and water-layer thickness.

The FO-DTS and MER cables were permanently installed into the estuary floor to enable repeatable geometries and rapid acquisition of data on return trips for periodic, long-term monitoring. The cables were installed such that typically high tide came to about 5 or $6 \mathrm{~m}$ and low tide came to about 10 or $12 \mathrm{~m}$ along the cables. Additional data collection included bay temperature, water level (tide), and specific conductivity from a YSI sonde installed in the vicinity of the study area. Atmospheric data also were available from meteorological sensors maintained by WBNERR.

\section{Results}

The FO-DTS temperature data are displayed as a color transect for the duration of the field activities (Figure 2a) to show the resolution of the method in both space and time. The most striking feature in this dataset is the cold anomaly that develops near-shore (10 to $15 \mathrm{~m}$ ) around low tide. This feature persists through the 4 weeks of data collection and is interpreted as the location of SGD. General cooling of the temperature can be observed in response to multiple days of cloud cover and precipitation. Additionally, temperatures near shore appear to be dominated by a semi-diurnal signal, whereas temperatures farther off shore appear to be dominated by a diurnal signal (Figure 2b and 2c, respectively). Time-series temperature data of specific locations near shore and off shore (Figure 3) also

\footnotetext{
${ }^{1}$ The use of trade, product, or firm names in this publication is for descriptive purposes only and does not imply endorsement by the U.S. Government.
} 
display the diurnal and semi-diurnal signals. It appears that the semi-diurnal signal correlates with the time series of bay tidal level and the diurnal signal correlates with the time series of bay temperature.

The MER tomograms display the subsurface resistivity distribution; an example for an 18-hour period is shown in Figure 4a-4t. The high-tide tomograms (e.g., Figures 4a-4e) show slightly more resistive features near shore, indicating that the sediments are saturated with ground water that is slightly less conductive than the bay water at high tide. As the tide falls, the resistivity values increase markedly near shore and a high resistivity anomaly forms (e.g. Figures 4g-4k). The resistivity anomaly indicates that fresh ground water has displaced the conductive water in the sediment pore spaces. As the tide transitions and begins to rise, the near shore resistive anomaly fades and returns to high-tide values. The resistive features appear to be dominated by a semi-diurnal signal in the near-shore environment with very little change occurring in the resistivity values off shore.

There is good correlation between the locations of the cold temperature anomaly observed in the FO-DTS data (Figure 2a) and the resistive anomaly observed in the MER data (Figure 4). Both anomalies are observed at 10 to $15 \mathrm{~m}$ along the FO DTS and MER cables, respectively, or close to the low-tide location at the site.

\section{Conclusions}

Initial results indicate that the combination of FO DTS and MER is a useful strategy for monitoring changes in the complex estuarine environment of Waquoit Bay. The highly resolved measurements allow for the precise location of ground-water features. At Waquoit Bay, the temperature response in the near-shore environment appears to be influenced by the semi-diurnal tidal fluctuations, whereas the off-shore temperature response is more influenced by diurnal fluctuations associated with solar radiation heating and cooling of the baywater and sediments. Time-lapse resistivity measurements allow for interface visualization and monitoring changes in subsurface conductivity values. Although the resistive anomaly disappears as the tidal level increases, the temperature data indicate that the SGD area is not fully shut down by the tide. Rather, as the tide increases, saline waters fill the unsaturated pore spaces on the beach face and begin mixing with the underlying freshwater. The freshwater effectively "flushes" the pore spaces as the tide falls and the tidal pressure head exits the beach face.

Work is ongoing to further characterize the temperature signal with respect to the diurnal and semi-diurnal signals and to identify temperature response to precipitation events. Additionally, we are working to more fully account for changes in water-layer thickness over the tidal cycle using a finiteelement model with an irregular mesh.

\section{References}

Abraham, D.M., Charette, M.A., Allen, M.C., Rago, A., and Kroeger, K.D., 2003, Radiochemical estimates of submarine groundwater discharge to Waquoit Bay, Massachusetts, The Biological Bulletin, v. 205, p. 246-247.

Bear, J., 1979, Hydraulics of Groundwater, McGraw-Hill, Inc., 569 p.

Belaval, M., Lane, J.W., Jr., Lesmes, D.P., and Kineke, G.C., 2003, Continuous-resistivity profiling for coastal groundwater investigations: three case studies, in Symposium in the Application of Geophysics to Engineering and Environmental Problems (SAGEEP), April 6-10, 2003, San Antonio, Texas, Proceedings, Environmental and Engineering Geophysics Society, CD-ROM, 14 p.

Burnett, W.C., Aggarwal, P.K., Aureli, A., Bokuniewicz, H., Cable, J., Charette, M., Kontar, E., Krupa, S., Kulkarni, K.M., Loveless, A., Moore, W.S., Oberdorfer, J.A., Oliviera, J., Ozyurt, N., 
Povinec, P., Privitera, A.M.G., Rajar, R., Ramessur, R.T., Scholten, J., Stieglitz, T., Taniguchi, M., Turner, J.V., 2006, Quantifying submarine groundwater discharge in the coastal zone via multiple methods, Science of the Total Environment, v. 367, p. 498-543.

Burnett, W.C., Bokuniewicz, H., Huettel, M., Moore, W.S., and Taniguchi, M., 2003, Groundwater and pore water inputs to the coastal zone, Biogeochemistry, v. 66, p. 3-33.

Cambareri, T.C., and Eichner, E.M., 1998, Watershed delineation and ground water discharge to a coastal embayment, Ground Water, v. 36, no. 4, p. 626-634.

Colman, J.A., Masterson, J.P., Pabich, W.J., and Walter, D.A., 2004, Effects of aquifer travel time on nitrogen transport to a coastal embayment, Ground Water, v. 42, no. 7, p. 1069-1078.

Day-Lewis, F.D., White, E.A., Johnson, C.D., Lane, J.W., Jr., and Belaval, M., 2006, Continuous resistivity profiling to delineate submarine groundwater discharge-examples and limitations, The Leading Edge, p. 724-728.

Hoefel, F.G., and Evans, R.L., 2001, Impact of low salinity porewater on seafloor electromagnetic data: A means of detecting submarine groundwater discharge?, Estuarine, Coastal and Shelf Science, V.. 52, p.179-189.

Johannes, R.E., 1980, The ecological significance of the submarine discharge of groundwater, Mar. Ecol. Prog. Ser. 3, p. 365-373.

Loke, M.H., 2004, Tutorial: 2-D and 3-D electrical imaging surveys, www.geoelectrical.com, (Accessed 3 December 2007.)

Lane, J.W., Jr., Day-Lewis, F.D., Johnson, C.D., Dawson, C.B., Nelms, D.L., Eddy-Miller, C.A., Wheeler, J.D., Harvey, C.F., and Karam, H., in press, Fiber-optic distributed temperature sensing: A new tool for assessment and monitoring of hydrologic processes [abs.], in Symposium on the Application of Geophysics to Engineering and Environmental Problems, April 6-10, 2008, Philadelphia, Pennsylvania, Proceedings, Environmental and Engineering Geophysical Society.

Manheim, F.T., Krantz, D.E., and Bratton, J.F., 2004, Studying ground water under Delmarva coastal bays using electrical resistivity, Ground Water, v. 42, no. 7, p. 1052-1068.

Michael, H.A., Lubetsky, J.S., and Harvey, C.F., 2003, Characterizing submarine groundwater discharge: A seepage meter study in Waquoit Bay, Massachusetts, Geophysical Research Letters, vol. 30, no. 6, 4 p.

Michael, H.A., Mulligan, A.E., and Harvey, C.F., 2005, Seasonal oscillations in water exchange between aquifers and the coastal ocean, Nature, v. 436, p. 1145-1148.

Miller, D.C., and Ullman, W.J., 2004, Ecological consequences of ground water discharge to Delaware Bay, United States, Ground Water, v. 42, no. 7, p. 959-970.

Moore, W.S., 1999, The subterranean estuary: a reaction zone of ground water and sea water, Mar. Chem., v. 65, p. 111-125.

Mulligan, A.E., and Charette, M.A., 2005, Intercomparison of submarine groundwater discharge estimates from a sandy unconfined aquifer, Journal of Hydrology, v. 327, 411-425.

Selker, J., Thevenaz, L., Huwald, H., Mallet, A., Luxumberg, W., van de Giesen, N., Stejskal, M., Zeman, J., Westhoff, M., and Parlange, M.B., 2006, Distributed fiber-optic temperature sensing for hydrologic systems, Water Resources Research, v. 42, p. 1-8.

Simmons, G.M., 1992, Importance of submarine groundwater discharge and seawater cycling to material flux across sediment/water interfaces in marine environments, Mar. Ecol. Progr Ser, 84, p. 173-184.

Slomp, C.P., and Van Cappellen, P., 2004, Nutrient inputs to the coastal ocean through submarine groundwater discharge: controls and potential impact, Journal of Hydrology, v. 295, p. 64-86. 
Smith, A.J., and Nield, S.P., 2003, Groundwater discharge from the superficial aquifer into Cockburn Sound Western Australia: Estimation by inshore water balance, Biogeochemistry, v. 66, p. 125144.

Swarzenski, P.W., Burnett, W.C., Greenwood, W.J., Herut, B., Peterson, R., Dimova, N., Shalem, Y., Yechieli, Y., and Weinstein, Y., 2006, Combined time-series resistivity and geochemical tracer to examine submarine groundwater discharge at Dor Beach, Israel, Geophysical Research Letters, v. 33, L24405, 6 p.

Taniguchi, M., 2002, Tidal effects on submarine groundwater discharge into the ocean, Geophysical Research Letters, v. 29, no. 12, p. 1-3.

Taniguchi, M., Turner, J.V., and Smith, A.J., 2003, Evaluations of groundwater discharge rates from subsurface temperature in Cockburn Sound, Western Australia, Biogeochemistry, v. 66, p 111124.

Urish, D.W., and McKenna, T.E., 2004, Tidal effects on ground water discharge through a sandy marine beach, Ground Water, v. 42, no. 7, p. 971-982.

\section{Acknowledgments}

This work was supported by the U.S. Geological Survey Ground-Water Resources Program. The authors are grateful to Hanan Karam (MIT) and Chris Wiedman (WBNERR) for field support; Ann Mulligan and Matt Charette (WHOI) for access to data; and Christopher Reich and Kamini Singha for comments on this work. We also thank the National Estuarine Research Reserve program for access to the WBNERR research site. 


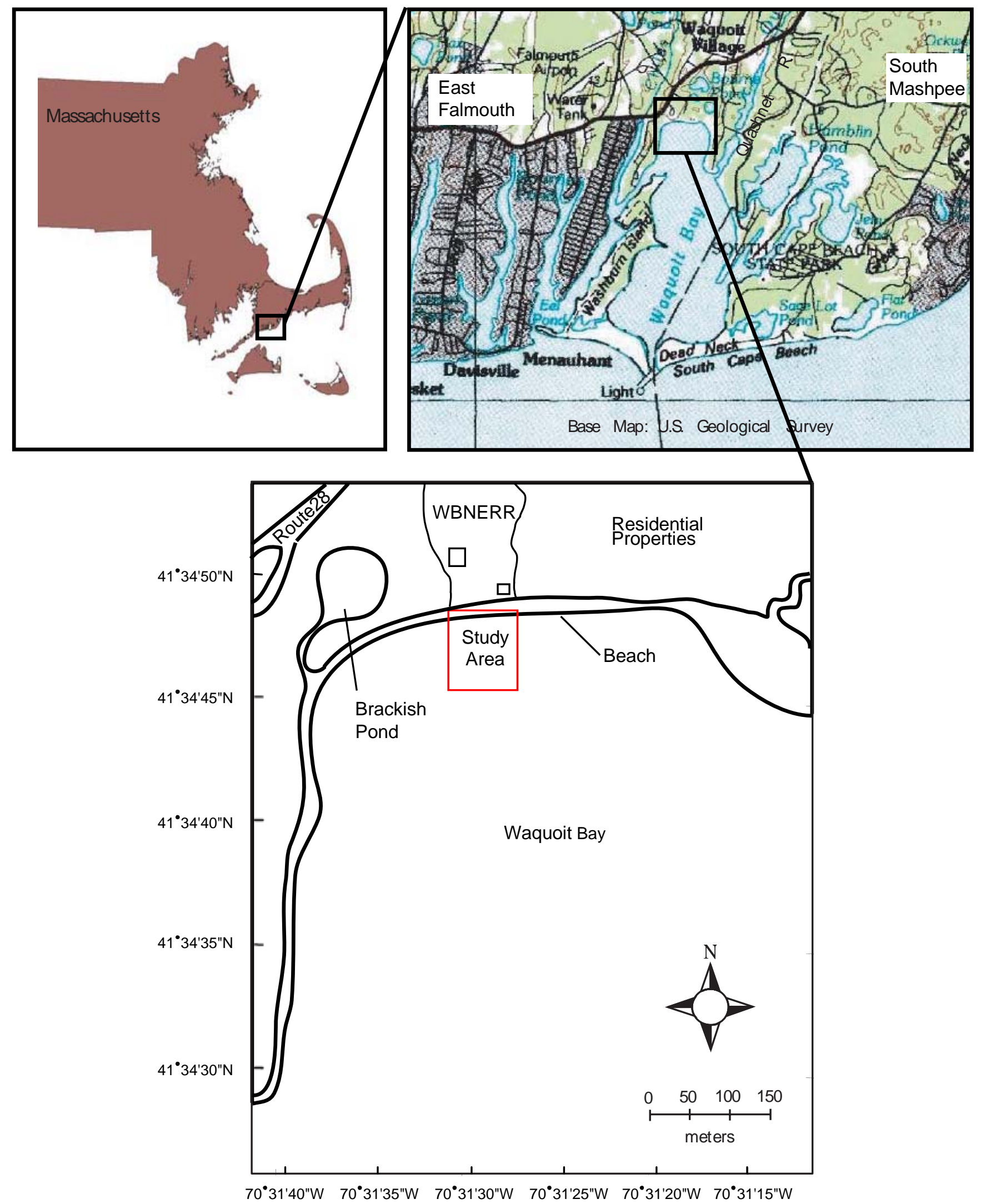

Figure 1: Waquoit Bay is a tidal embayment located on the south shore of Cape Cod, Massachusetts. 


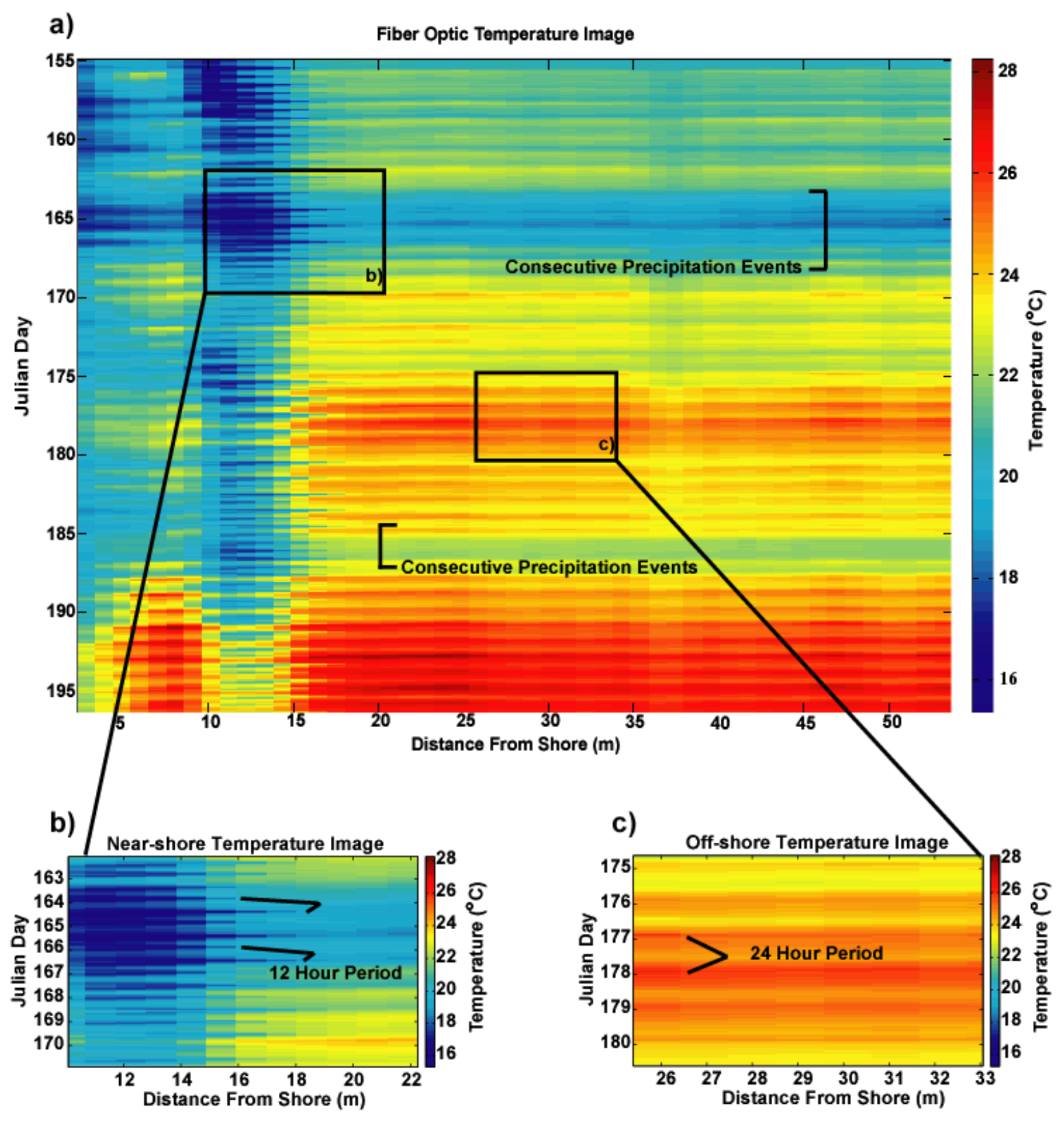

Figure 2: (a) Fiber-optic temperature data for the duration of the field experiment. Consecutive precipitation events are noted, resulting in a general cooling of temperature along the entire transect. (b) Enlarged example of data from close to shore that exhibits a periodicity of 12 hours, the semi-diurnal tidal signal. (c) Example of data from off shore, showing temperature dominated by the diurnal signal of solar heating and night time cooling. 

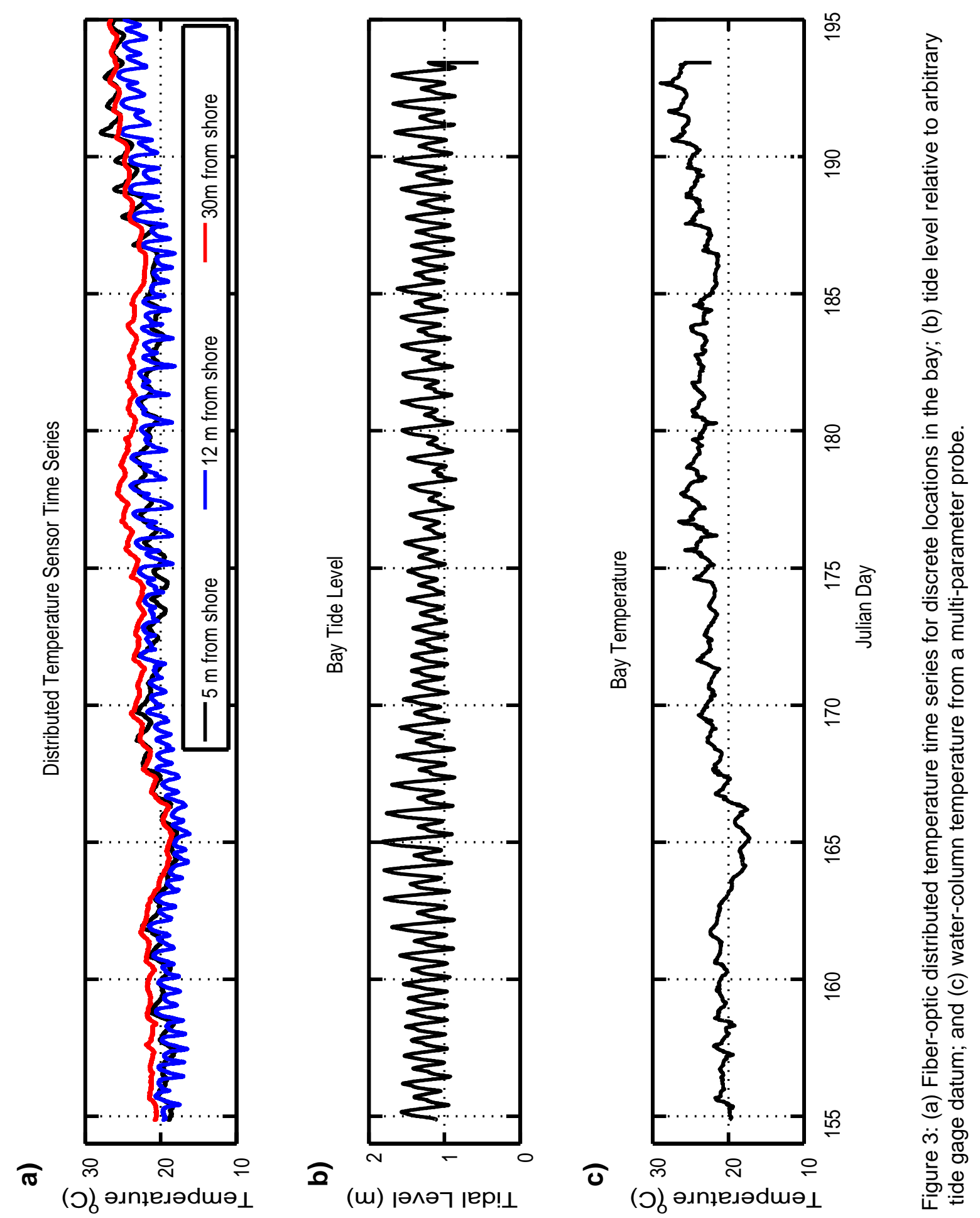

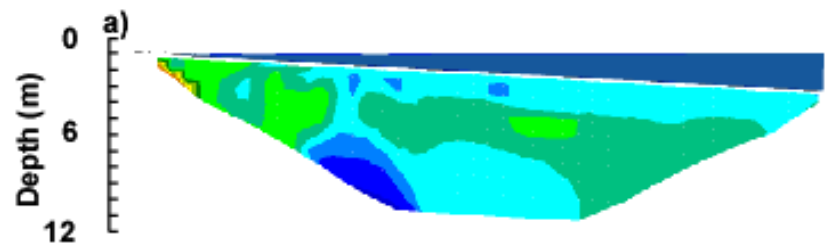

b)

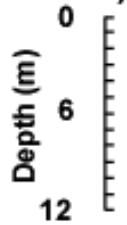

$\widehat{\mathrm{g}}^{\mathrm{z}}{ }^{0} \mathrm{E}$

c)
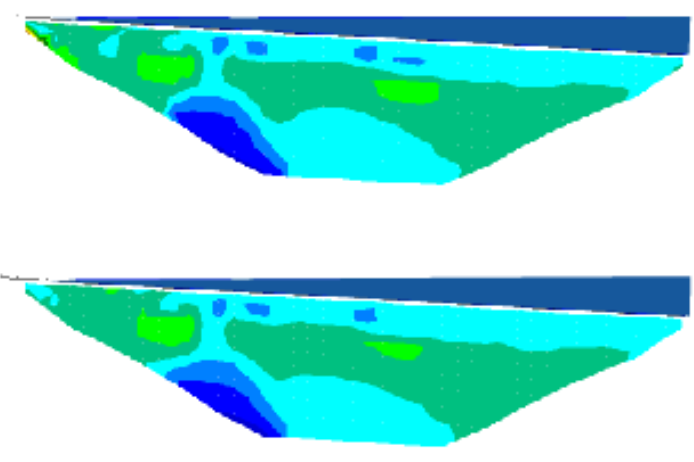

d)

吾 $^{0}$ E

${ }_{12}^{0}{ }^{0}{ }^{\mathrm{E}} 6$

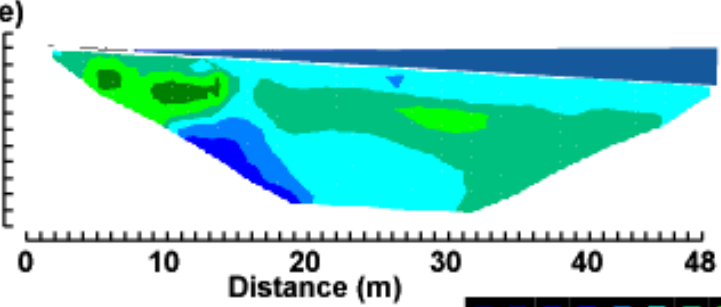

f)

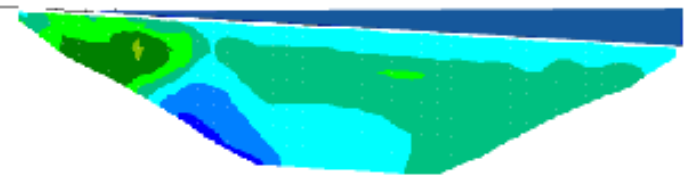

g)

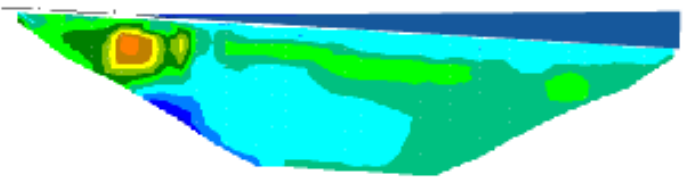

h)

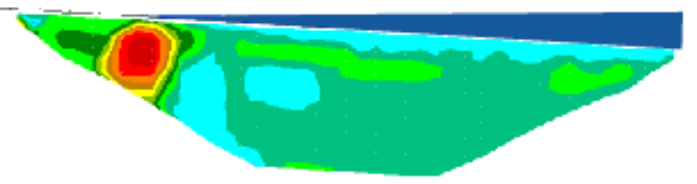

i)

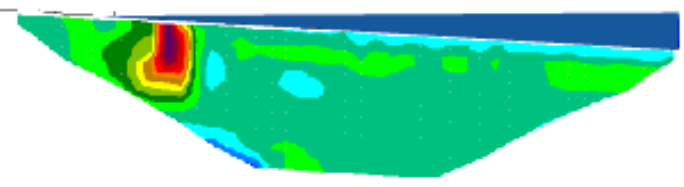

j)

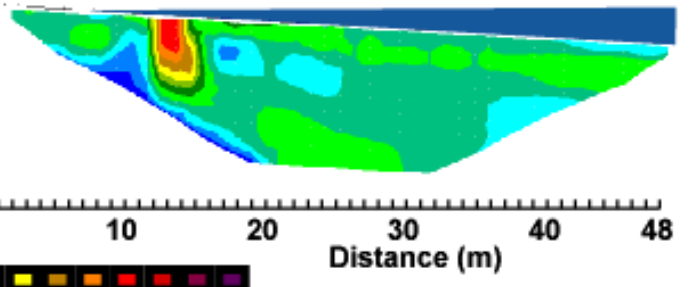

$0.02 \quad 0.08 \quad 0.32 \quad 1.285 .12 \quad 20.581 .9328$

Resistivity (ohm-m)

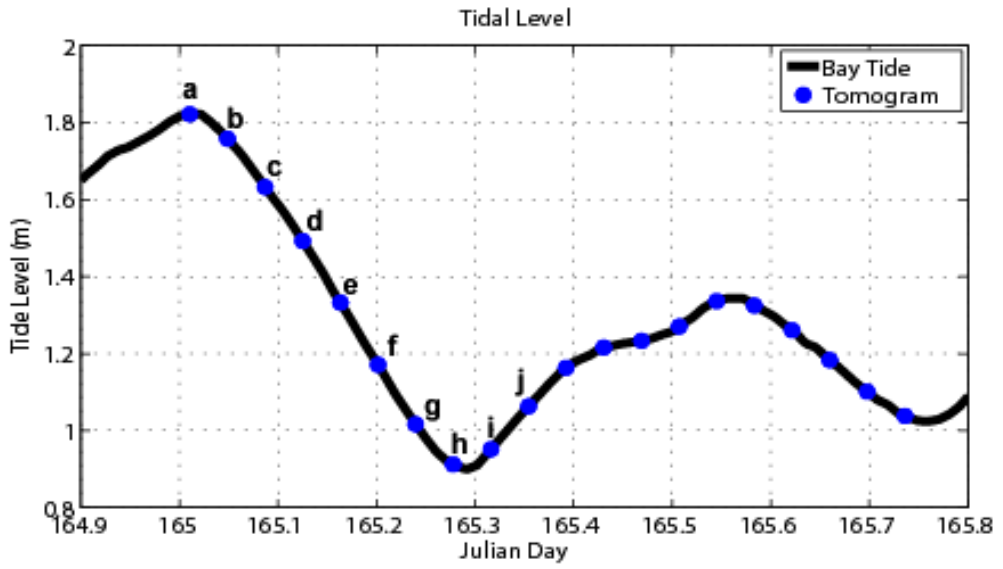

Figure 4: Tomograms for an 18-hour period (a-t). The tomograms begin at high tide (a) and progress through 1.5 tidal cycles. The tidal level corresponding to the tomograms is shown in the plots at the bottom of each page, where the blue dots are labeled with the corresponding tomogram identification letter (continued on next page). 


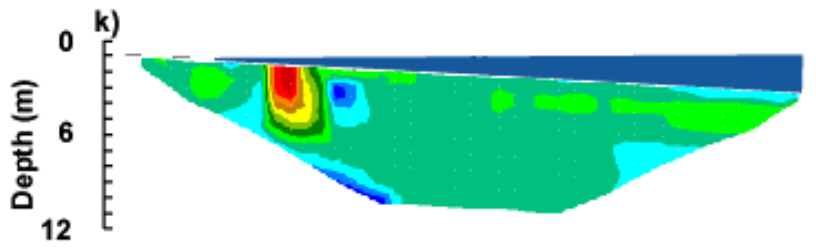

p)
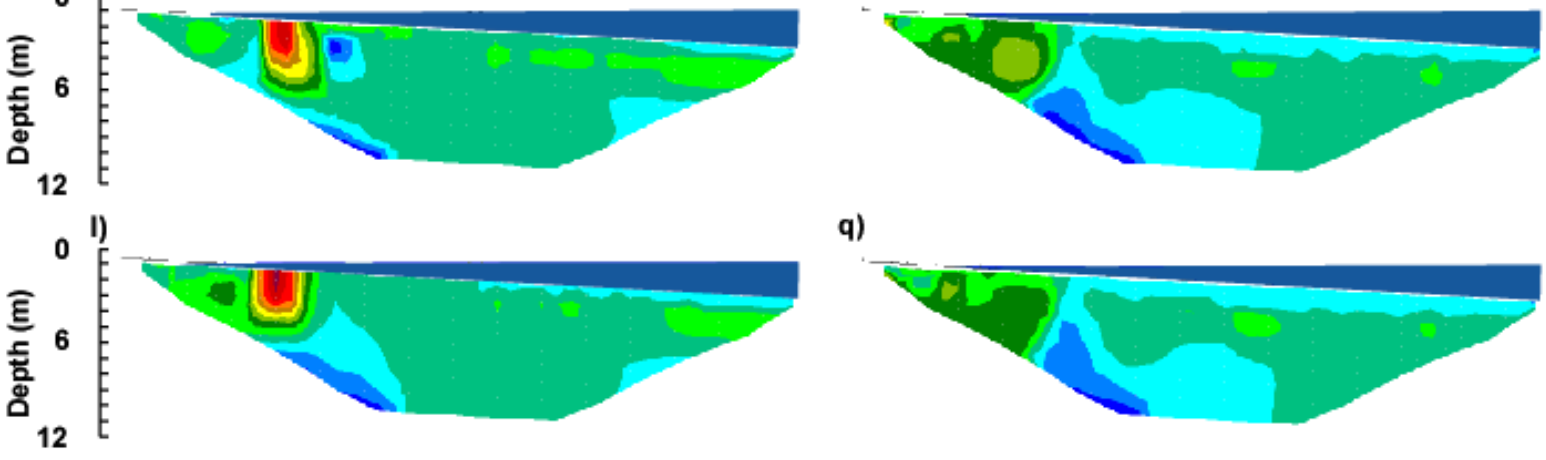

q)
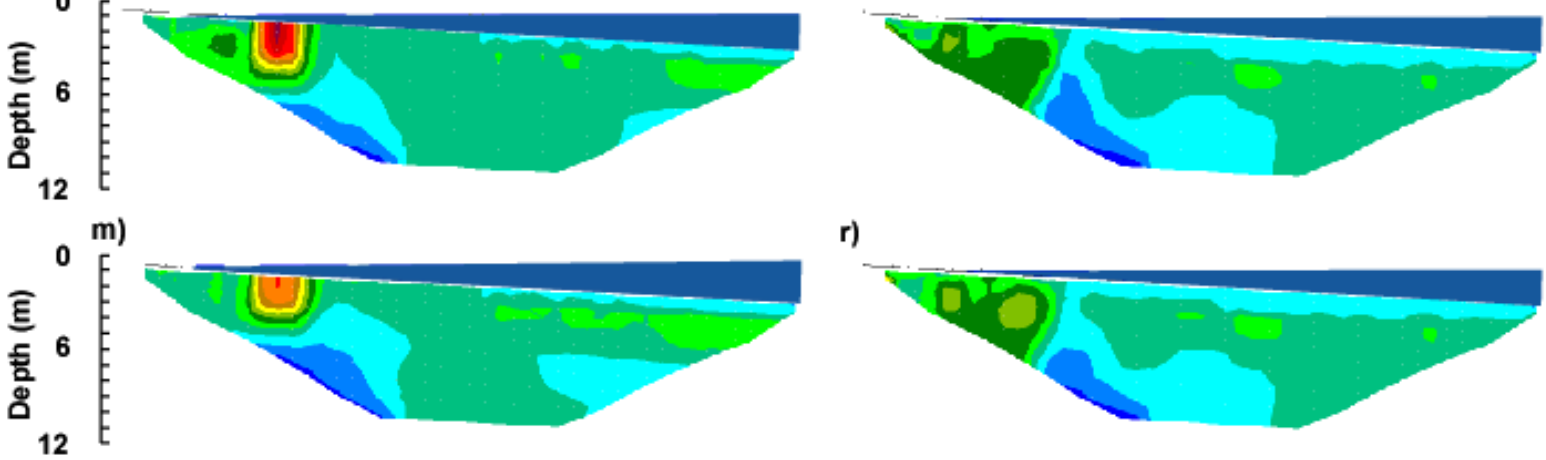

r)
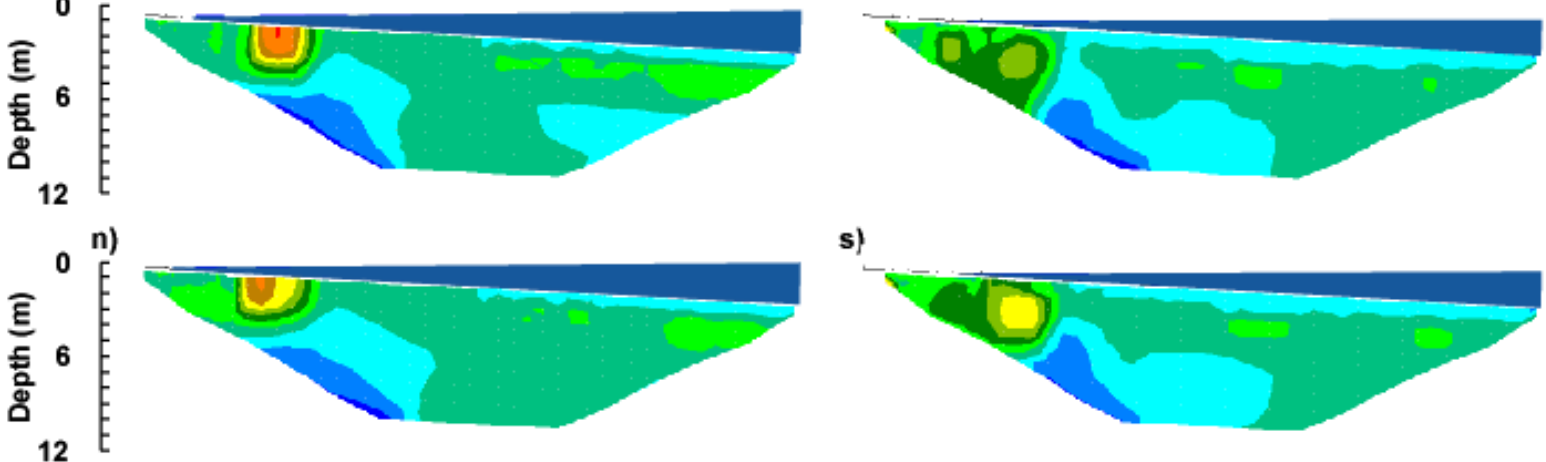

s)
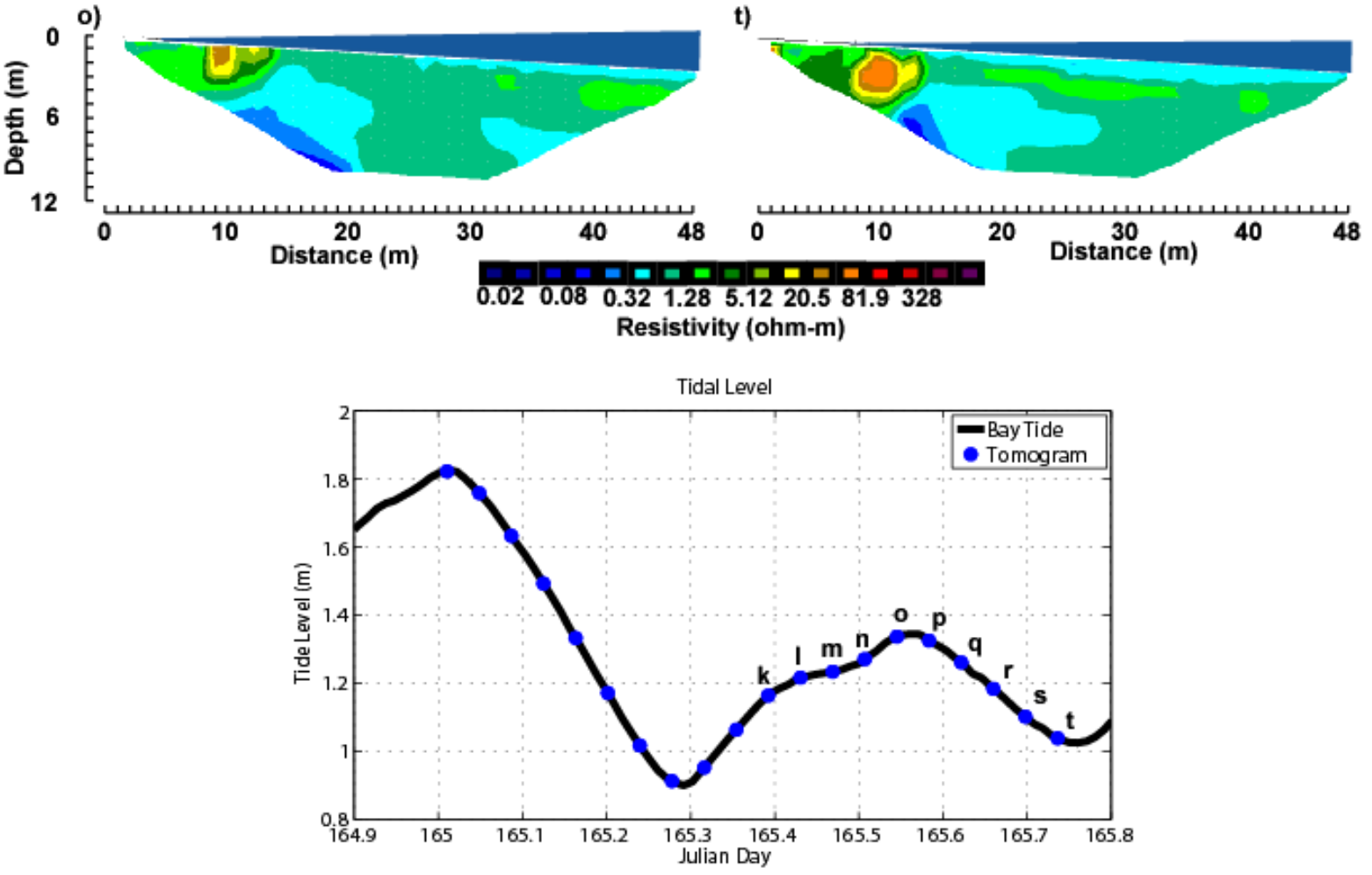

Figure 4: Continued. 